\title{
Para uma Sociologia da Experiência. Uma leitura contemporânea: François Dubet
}

ANNE MARIE WAUTIER*

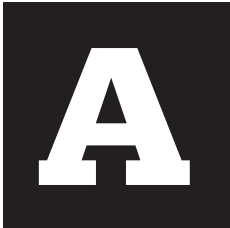

firmar que a Sociologia procura entender as mudanças que ocorrem na sociedade seria uma tautologia; desde sua criação, de Comte até hoje, ela não tem feito outra coisa. Mas o que faz a diferença hoje é, em primeiro lugar, e para citar apenas alguns aspectos mais relevantes, a extensão dessas mudanças. Elas não se limitam a uma área geográfica ou a uma parte hegemônica do mundo, como no séc. 19. Encontram-se hoje nos países do norte como nos do sul os mesmos problemas econômicos e suas conseqüências políticas e sociais: difícil transformação e sobrevivência da pequena agricultura, marginalização das minorias étnicas e de gênero, mudanças na estrutura do mundo do trabalho, e outras tantas. É também nítida a consciência de que estas mudanças não são mais inerentes à modernidade antes entendida como progresso. O "progresso", e suas conseqüências, chegou, de uma maneira ou outra, em toda parte (por exemplo, a poluição e os acidentes ecológicos, ou, num outro registro, a extensão das redes de comunicação). Novas configurações sociais se desenham, qualquer que seja o desenvolvimento econômico dos países, e novas demandas (educação, autonomia e reconhecimento das minorias, participação política) podem ser até tratadas com violência quando não atendidas:

* Professora na UNIJUÍ (RS), doutoranda em Sociologia na UFRGS. 
manifestações de rua, atentados, seqüestros. Enfim, a diferença aparece também nas aparentes contradições ou incoerências que pontuam essas mudanças; os movimentos de libertação nacional assemelham-se mais a retrocessos comunitários do que a avanços democráticos (País Basco, Afeganistão, Indonésia); os últimos bastiões comunistas abrem as portas aos maiores símbolos capitalistas (Bolsas de valores, fast-food); recrudescência dos movimentos carismáticos, gerenciados como negócios rentáveis (ingressos à venda para uma "missa-show" de um conhecido padre, comércio dos "anjinhos", etc.).

Resumindo, a sociedade, no mundo inteiro, parece ter perdido a bússola e as instituições tradicionais parecem não ser mais capazes de enquadrar novas demandas que traduzem uma ânsia de reconhecimento e de respeito de sua especificidade, seja na Igreja, na família, na escola, nos partidos políticos, nas organizações de produção. Como podemos ler e interpretar essas mudanças nos valores e condutas que faziam parte de nosso horizonte até há bem pouco tempo? A Sociologia está em busca de outras balizas para a compreensão desta nova configuração social em que há, pelo menos, acordo sobre um ponto: as explicações fornecidas até hoje não cabem mais neste "admirável mundo novo".

Entretanto, esta situação crítica não era inteiramente imprevisível. Já no séc. 19, no auge da ideologia do progresso e da concepção ordenada da sociedade, Simmel, este pensador mal amado por sua originalidade e independência, advertia: o homem moderno não pode mais fazer parte das unióes tradicionais ou engajar-se em vínculos estreitos que não respeitam suas preferências e sua sensibilidade pessoal.2 Sua interrogação sobre a sociedade e o indivíduo, sobre suas ações recíprocas, são próximas das idéias desenvolvidas mais tarde por Weber. Simmel vai ser redescoberto na França e influenciar o pensamento de Touraine e da equipe de pesqui-

1 Em referência à obra de Aldous Huxley: Um admiráve/ mundo novo.

2 Simmel, Georg. Sociologie. Recherche sur les formes de socialisation. 1908. In: Van Meter, Karl. p. 253. 
sadores do CADIS (Centro de Análise e de Intervenção Sociológica). Entre eles, quem dá uma atenção particular à análise teórica da sociedade contemporânea vinculada ao estudo dos fundamentos teóricos e metodológicos das pesquisas empíricas é François Dubet, através do conceito de experiência social.

O objetivo deste artigo é aprofundar a compreensão deste conceito, não só de um ponto de vista teórico, mas nas suas possibilidades de operacionalização. Isto é, como pode esse conceito, fundamentado teoricamente, permitir a compreensão das expressões contemporâneas da sociedade, na sua aparente crise de valores, ambigüidades e incoerências? Em primeiro lugar, apresentar-se-á a reflexão feita por Dubet, assim como o desdobramento dessa reflexão na sua tentativa de resposta à pergunta: "Em que sociedade vivemos?". ${ }^{3}$ Em segundo lugar, será feita uma rápida incursão ao pensamento de dois autores referenciados por Dubet: Simmel e Schutz, que ilustram as duas vertentes da experiência: a ação social e a subjetividade.

\section{A Experiência Social}

\section{A construção do conceito}

\section{A "decomposição" do modelo clássico de análise da sociedade}

O ponto de partida de Dubet é a constatação de uma mudança profunda na concepção da sociedade, do indivíduo e da ação social, de uma "decomposição" da representação do social oferecida pela sociologia clássica. Esta poderia ser identificada, segundo ele, de maneira ampla, não

3 Para Dubet, Sociologie de l'expérience, 1994: as citações feitas neste texto são da edição original em francês. Para Dubet e Martuccelli, Dans quelle société vivons-nous?, 1998: as citações são da edição argentina. Ver referências completas na bibliografia. Para as duas obras, as traduções são minhas. 
desprovida de arbitrariedade, às obras de Durkheim e de Parsons, assim como à apresentação feita por Nisbet da tradição sociológica (Dubet, 1994, p. 11). E, mesmo que vários sociólogos de renome não se enquadrem nesta perspectiva clássica, foi ela que forneceu referências básicas comuns à Sociologia, compartilhadas durante tanto tempo que elas acabaram adquirindo um caráter 'clássico'(Id., p. 22).

No pensamento clássico, a sociedade é uma noção central, é uma realidade altamente integrada e integradora: A sociedade existe como um sistema integrado identificado à modernidade, a um Estado-Nação e a uma divisão do trabalho elaborada e racional. Ela também existe porque produz indivíduos que interiorizam seus valores e realizam suas diversas funções (Id., p. 21). Definir a sociedade na sociologia clássica equivale a traçar seu nível de desenvolvimento, seu grau de racionalidade, sua capacidade de assegurar a ordem e a segurança no quadro de um Estado apoiado em instituições sólidas. Se a idéia de sociedade é a representação da "ordem e progresso", ela também é intimamente vinculada à idéia de sociedade industrial, hierarquizada e, logo, conflituosa (divisão do trabalho). Mas o conflito, mesmo que seja tido como disfunção, é fator de elaboração de novos ajustes e acaba tendo uma função de adaptação e de integração dos atores em conflito (...) estabelecendo fronteiras mais nítidas entre os diversos grupos (Id., p. 49). Esta representação está hoje colocada em xeque.

A idéia de sociedade associada à modernidade e ao progresso revelou-se, nos fatos, mais na ruptura do que numa evolução harmoniosa, seja nos Estados revolucionários marxistas ou nos novos Estados descolonizados. A ideologia do progresso gerou reações nacionalistas e uma dualização econômica e social das sociedades, provocando a crítica não só por parte da sociologia marxista como também dos próprios funcionalistas. O Estado-Nação não é mais a encarnação da idéia de sociedade, já que a internacionalização da economia e da cultura colocam em questão a soberania nacional e as identidades culturais. Aparecem novas formações 
políticas (Mercosul, União Européia) e, ao mesmo tempo, descentralização de certas prerrogativas e responsabilidades em políticas públicas. ${ }^{4}$ Enfim, assiste-se ao declínio da sociedade industrial e da consciência de classe que estavam no cerne da vida social, tanto na perspectiva marxista quanto na perspectiva funcionalista: as relações de produção não são mais a única fonte de identificação dos atores. Hoje se leva também em conta o sexo, a etnia, a qualificação, entre outras. A focalização dos problemas sociais se desloca da fábrica para a cidade, ${ }^{5}$ da dominação econômica para outras formas de desigualdades, da integração à produção para uma participação social mais ampla.

Na sociologia clássica, o ator individual é definido pela interiorização do social (Id., p. 12), o que implica um importante autocontrole, tal como a interiorização das normas, a consciência do dever e das obrigações morais; também submete o indivíduo a um rígido controle social, o indivíduo é produto de uma socialização que visa a incorporação de valores e de condutas socialmente adaptadas ao funcionamento da sociedade. "O 'eu' sem o 'nós' é patológico", segundo Elias, citado por Dubet. Questiona-se hoje esta concepção do ator individual. A crítica da modernidade, já iniciada por Simmel e Weber (ld., p. 19) e continuada, entre outros, por Touraine (Id., p. 73), não defende mais, como na sociologia clássica, o papel social do indivíduo e a unidade da sociedade, mas a autenticidade e a identidade do sujeito, a afirmação de si e o desejo de ser "autor da sua vida": a figura clássica de um indivíduo constituído por um todo social homogêneo não parece mais aceitável (Id., p. 74). Mas, por outro lado, esta mesma crítica não deixa de censurar o individualismo que se sobrepõe ao indivíduo, o individualismo da sociedade de consumo incapaz de fazer seus

4 No caso do Brasil, seria, por exemplo, a "municipalização" da saúde, do ensino...

5 Cidade, entendida como espaço mais amplo de embates sociais do que apenas a fábrica, muito tempo considerada como terreno privilegiado das relações sociais. Seja nas sociedades "ocidentais" ou nas sociedades "dependentes", Dubet sublinha o surgimento de problemas sociais, étnicos e religiosos que se superpõem às diferentes formas de exclusão do trabalho (Dubet, 1994). 
alguns valores essenciais a partir dos quais ele constrói a sua identidade e a sua ação (Id., p. 70). Esta forma de individualismo leva, não à "neurose da era vitoriana", mas a uma profunda crise de identidade e a uma indiferença que ameaça a sociedade e a democracia.

Enfim, na sociologia clássica, a ação social é a realização de um papel integrado, interiorizando normas e princípios reconhecidos pelos atores e visando a coesão do sistema. Existe um vínculo de inclusão do ator e do sistema (Id., p. 13), uma identificação total entre os dois, isto é, a identidade do ator e do sistema pelo viés da noção de ação (ld., p. 50). Hoje em dia, esta perspectiva se desfaz. Numa sociedade que se caracteriza pela diversidade cultural, pela multiplicidade das formas de conflito e de ação social, os atores não podem mais ser reduzidos a um só tipo de papel programado, não podem atuar segundo uma lógica única e determinada: o ator e o sistema se separam. Não existe mais um paradigma único da ação. A ação social não é determinada tão somente pelo sistema. O indivíduo se destaca pela capacidade de distanciamento em relação ao sistema e pela sua capacidade de iniciativa e de escolha. Segundo Dubet, é na ação que se constrói um conhecimento da sociedade. Ele distingue uma vertente comunicacional ou fenomenológica: a ação é interação (Goffman e as relações face to face) e é linguagem (Schutz e Garfinkel). Outra é a vertente da ação racional, que pode ser estratégica (Crozier e Friedberg e a racionalidade limitada dos atores), ou princípio de utilidade (Boudon e o individualismo metodológico).

Dessa forma, estamos presenciando uma fragmentação do modelo clássico de análise da sociedade e uma multiplicidade de paradigmas da ação: a dispersão se tornou regra e a combinação dos modelos substitui a antiga unidade (ld., p. 90). A diversidade das lógicas de ação pode ser atualmente o problema mais crucial da análise sociológica. Mas a reflexão sobre a ação social parece estabelecer hoje um princípio de unidade do pensamento sociológico além da diversidade dos paradigmas (Id., p. 90). 
Um modo de recomposição do real: a experiência social

Segundo Dubet, a diversidade das lógicas de ação e as exigências de individualização que aparecem nas condutas sociais hoje são as formas tomadas pela experiência social moderna, já anunciadas por Weber (diversas formas de ação social) e Simmel. Para este, a fragmentação da experiência social era o fundamento mesmo da modernidade (a figura emblemática é o estrangeiro; Id., p. 74-75), em contraposição à homogeneidade funcional e à institucionalização das condutas. A experiência social se apresenta, assim, como capaz de dar um sentido às práticas sociais. Ela designa as condutas individuais ou coletivas dominadas pela heterogeneidade de seus princípios constitutivos e pela atividade dos indivíduos que devem construir o sentido de suas práticas no meio desta heterogeneidade (Id., p. 15).

O conceito evidencia três traços essenciais que aparecem nas mais diversas condutas sociais. O primeiro é a heterogeneidade dos princípios culturais e sociais que organizam as condutas (Id., p. 16): a identidade social, construída a partir desses princípios, não é um ser (posição social) mas um fazer, um trabalho, uma construção, uma "experiência". Enquanto, na concepção clássica da ação, a personalidade (o ator) é determinada pelos papéis (normas, meios), nesse caso, o papel é produzido pela personalidade, isto é, uma nova capacidade de "gerenciar" a experiência. O segundo traço é a distância subjetiva que os indivíduos mantêm com o sistema (Id., p. 17). A pluralidade das lógicas de ação presente na experiência social é vivida como um problema e produz uma atitude de distanciamento, de mal-estar. Os indivíduos precisam explicar a si mesmos como constroem suas práticas, sua adesão (relativa) a papéis e valores aos quais eles não conseguem aderir completamente. ${ }^{6}$ Esta distância crítica (reflexividade), quando ocorre, define a autonomia dos atores, torna-os sujeitos, já que os atores não podem ser enclausurados nos seus papéis, 
observa Dubet (Id., p. 18). Enfim, o terceiro traço sublinha o fato de que a construção da experiência coletiva recoloca o conceito de alienação no cerne da análise sociológica (Id.). Com o declínio da idéia clássica de sociedade, não existe mais um "conflito central" nem movimento social capaz de agregar os indivíduos num projeto comum. O que há são explosões sociais localizadas, e a alienação ocorre quando as relações de dominação impedem os atores de terem o domínio sobre sua experiência social (Dubet dá o exemplo dos jovens das periferias urbanas, p. 18). A experiência social aparece como uma maneira de construir o mundo, ao mesmo tempo subjetiva (é uma "representação" do mundo vivido, individual e coletiva) e cognitiva (é uma construção crítica do real, um trabalho reflexivo dos indivíduos que julgam sua experiência e a redefinem). Experiência não alheia à alienação, como já comentado.

E Dubet vai definir a experiência como objeto sociológico:

A sociologia da experiência social visa definir a experiência como uma combinatória de lógicas de ação que vinculam o ator a cada uma das dimensões de um sistema. O ator deve articular estas lógicas de ação diferentes e a dinâmica que resulta desta atividade constitui a subjetividade do ator e sua reflexividade (Id., p. 105).

2 A sociologia da Experiência como sociologia da ação e do ator

As lógicas da ação

O "conjunto" social é uma justaposição de três grandes tipos de sistemas: ${ }^{7}$ comunidade, mercado e sistema cultural. Este último é a definição de uma criatividade humana que não pode ser reduzida à tradição ou à utilidade (Id., p. 110). Cada um destes sistemas é fundado numa lógica

7 Encontramos a mesma noção em Boaventura de Souza Santos sob o vocábulo de "pilares" (A crítica da razão indolente. São Paulo: Cortez, 2000. Vol. 1: Para um novo senso comum). 
própria. A experiência social é o resultado de uma articulação aleatória entre estas três lógicas:

- a integração: o ator é definido pelos seus vínculos na comunidade;

- a estratégia: o ator é definido por seus interesses num mercado;

- a subjetivação: o ator é um sujeito crítico frente a uma sistemática de produção/ dominação, de alienação. ${ }^{8}$

Lógicas autônomas e não hierarquizadas, ao contrário da idéia clássica de sociedade em que o Estado-Nação articulava e confundia a comunidade, o mercado e a cultura. É melhor, segundo Dubet, falar em 'experiência' do que em 'ação', para destacar mais a autonomia de cada uma destas lógicas (Id., p. 112). E, neste momento de sua reflexão, Dubet reconhece sua herança tourainiana no uso das categorias analíticas de identidade, oposição e totalidade (IOT), que inspiram sua tipologia da ação: Toda formação social é definida pela co-presença de uma capacidade de integração comunitária opondo o 'nós' aos 'outros', de um sistema de convivência regulada e de uma cultura definindo a capacidade crítica e a capacidade de ação voluntária (ld., p. 111).

Temos, no Quadro 1, uma esquematização destas três lógicas apresentadas a partir de quatro critérios: a forma da identidade do ator, a natureza das relações sociais, o que fundamenta a ação dos atores e a que tipo de visão de sociedade, de sistema social se refere.

A primeira, a integração, é a lógica de ação da sociologia clássica, assim como foi definida anteriormente. Para essa lógica, a identidade é "adscrição", submissão pela interiorização de valores institucionalizados através dos papéis. O ator é reconhecido na medida em que ele está integrado. As relações sociais são caracterizadas pela oposição entre "eles" e "nós". ${ }^{9}$ O outro é definido pela sua diferença, definido como o "estranho"

8 Na perspectiva de Dubet, a subjetivação é uma postura crítica, uma lógica de ação fundada na subjetividade, entendida como alicerce da experiência social e própria a um indivíduo (mas não é sinônimo de individualismo).

9 Dubet dá o exemplo dos ritos de passagem (é assim que se poderia entender também o trote de iniciação à vida universitária). 
contrário a "nós", ao grupo (in-group/out-group). O que fundamenta a ação são os valores. Para o ator, a cultura, ao mesmo tempo, fundamenta a identidade, é uma moral e perpetua a ordem. (Dubet dá o exemplo da religião e da escola, Id., p. 117). Enfim, a lógica da integração considera as condutas de crise, como patológicas, como falhas da socialização e da integração ao sistema. Nessa lógica, que domina a visão clássica da sociedade, os indivíduos têm como objetivo manter a continuidade de sua identidade.

Na lógica da estratégia, a identidade é um recurso, um meio, num mercado concorrencial, mercado entendido não só do ponto de vista econômico, mas em todas as atividades sociais. A identidade é vinculada ao conceito de status e não mais a um papel. $\mathrm{O}$ ator é reconhecido na medida em que ele pode, em que tem recursos para influenciar os outros a partir da posição que ele ocupa; não se trata mais de posição social, mas de posição "relativa", porque depende das oportunidades e dos recursos disponíveis nessa posição. A identidade é o meio para atingir determinados fins, e a integração é substituída pela regulação: as regras do jogo. As relações sociais são definidas em termos de concorrência, de rivalidade de interesses individuais ou coletivos. O que está em jogo na ação, neste caso, é o poder. Os atores vão definir seus objetivos, escolher o que para eles é útil, enfrentar a concorrência com os outros (pode ser pelo dinheiro, mas também competição política, conquista amorosa) e vão desenvolver estratégias para influenciar os outros, isto é exercer um poder. Nesta perspectiva, a ação coletiva é mais mobilização que adesão, os movimentos sociais são uma ação racional e não espontânea, e visam a exercer influência sobre o sistema político. A referência é a sociologia da ação estratégica, é a ação orientada para o sucesso (Habermas citado por Dubet. Id., p. 126), identificada à ideologia do capitalismo. Mas também é uma visão liberal, que denuncia tudo o que pode impedir a formação de equilíbrios harmoniosos numa sociedade aberta às trocas concorrenciais. 
A subjetivação, como lógica do sujeito, é um conceito de difícil definição visto, segundo Dubet, o uso que foi feito do termo numa perspectiva determinista ou individualista. Entretanto, a lógica do sujeito não pode reduzir o ator a seus papéis ou a seus interesses. Ela é uma atividade crítica. É a lógica pela qual o ator se diferencia da lógica de integração e da lógica estratégica. Quanto à identidade, o ator é, na qualidade de sujeito, na medida em que ele é capaz de se distanciar de si mesmo e da sociedade. Sua identidade é definida como um engajamento permitindo a ele de se perceber como o autor de sua própria vida (ld., p. 128), engajamento realizado no sofrimento: pela necessidade de distanciamento crítico e pela dificuldade de alcançar esta qualidade de sujeito. As relações sociais são percebidas em termos de obstáculos ao reconhecimento e à expressão desta subjetividade (Id., p. 130). O conflito social não é nem defesa da identidade nem mobilização racional; é a luta contra a alienação, no sentido da impotência, do sentimento de não ser nada mais do que o espectador de sua própria vida. Esta lógica da ação/subjetivação permite entender o irracional e o excessivo nos movimentos sociais nos quais podemos encontrar um ator que se percebe como sujeito. O que está em jogo nesse caso, é a cultura, entendida como "definição histórica do sujeito" e não mais apenas e unicamente valor que sustenta a sociedade, funda a moral, a ordem (Durkheim, Parsons). A cultura é o que torna possível a crítica social como fundamento da ação, não a partir de princípios transcendentais, mas como experiência social banal do senso comum (Id., p. 132). A lógica da subjetivação, na sua referência ao sistema social, está associada a uma postura crítica que denuncia a alienação e a dominação. A alienação se entende como privação da capacidade de ser sujeito (ld., p. 133) pela reificação das relações sociais; entende-se como desencantamento que esvazia a experiência social do seu sentido, através da racionalidade instrumental. 
Quadro 1. O "conjunto social": As lógicas de ação

\begin{tabular}{|c|c|c|c|c|c|c|}
\hline 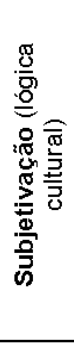 & 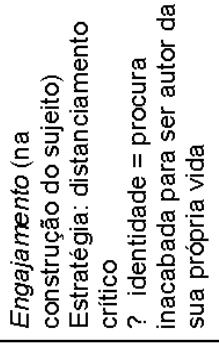 & 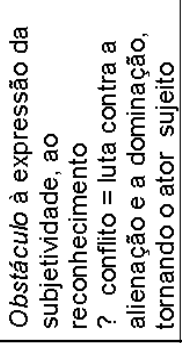 & 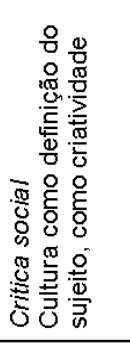 & 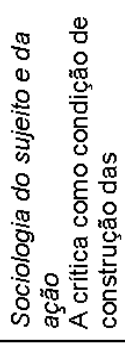 & 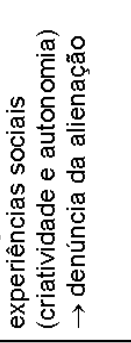 & 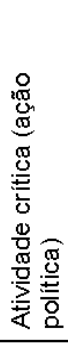 \\
\hline 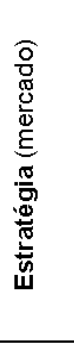 & 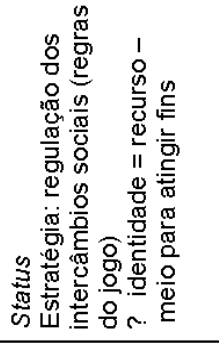 & 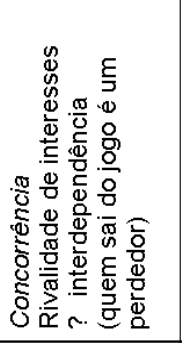 & 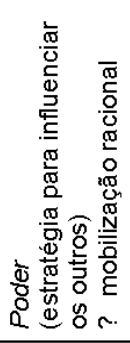 & 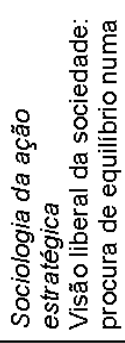 & 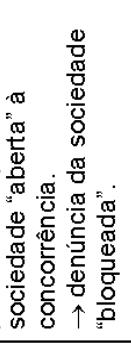 & 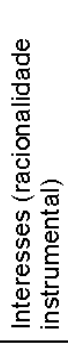 \\
\hline 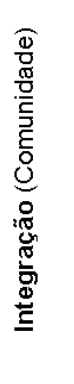 & 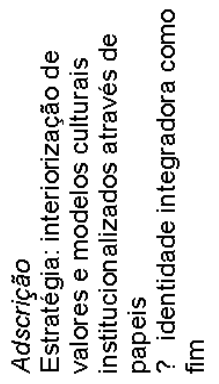 & 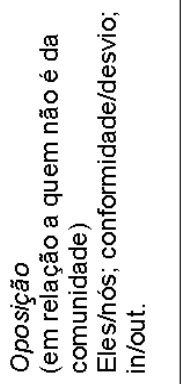 & 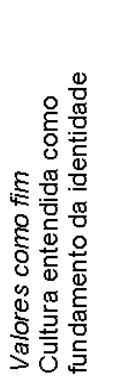 & 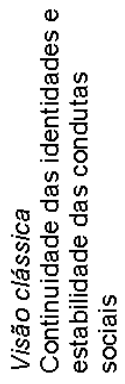 & 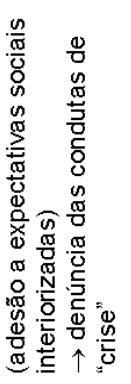 & 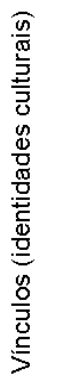 \\
\hline 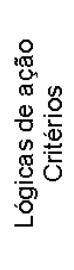 & 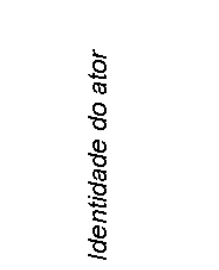 & 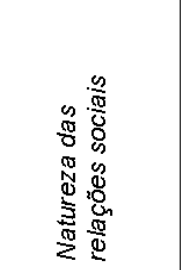 & 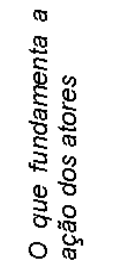 & 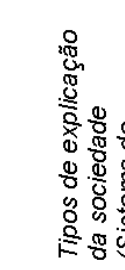 & & $\begin{array}{l}\stackrel{0}{0} \\
0 \\
0 \\
1 \\
0 \\
0 \\
0 \\
0 \\
0 \\
0\end{array}$ \\
\hline
\end{tabular}

Fonte: Dados elaborados a partir da obra de Dubet 
Existem, assim, três lógicas que remetem a três "elementos do conjunto de uma formação social", a três "sistemas" que são três tipos de explicação da sociedade. Mas para o ator, existe uma "circulação" entre esses três pontos de vista, que apaga a idéia clássica de sociedade como sistema fechado, como máquina. Os atores enfrentam identidades e relações sociais cada vez mais diversificadas. Eles não escolhem, mas se deparam com todas elas, ao mesmo tempo.

\section{A relação entre experiência social e sistema}

A experiência social não é algo sem relações com o sistema social: $O$ ator constrói uma experiência que lhe pertence, a partir de lógicas de ação que não Ihe pertencem, e que são dadas pelas diversas dimensões do sistema que vão se separando na medida em que a imagem clássica de unidade funcional da sociedade se desfaz (Id., p. 136). Assim, as experiências sociais são "combinações subjetivas de elementos objetivos", combinação de vários tipos de ação. Mas como podem estas lógicas ser articuladas com um dos modos de explicação da sociedade? Por que tipo de mecanismos?

O Quadro 2 desenha a relação entre lógicas de ação e sistema. ${ }^{10}$ Num sistema integrador, é a socialização - reprodução que funda a lógica de integração. Seja sob forma de educação ou sob forma de controle social, ela orienta as condutas e a ação social. No sistema de interdependência, a racionalidade do ator é submetida a vários tipos de coerções e é limitada. Mas o mercado preexiste e "a otimização da escolha é fixada pela distribuição dos recursos". Na relação ator/sistema, falar-se-á em termos de jogos de interesses e de regras do jogo (Crozier e Friedberg). O sistema impõe regras e coerções aos jogadores, mas nem todos jogam como gostariam de fazê-lo. A ação articula a racionalidade dos atores com regras e situações que dificultam o jogo e fazem uma distribuição desigual das capacidades de jogar (Id., p. 147). 
Quadro 2. A experiência social: relações entre lógicas de ação e sistema social

\begin{tabular}{|c|c|c|c|}
\hline 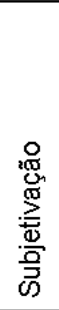 & 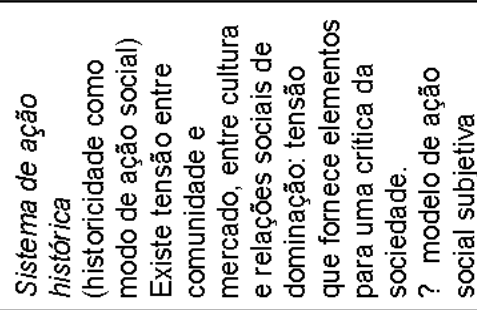 & 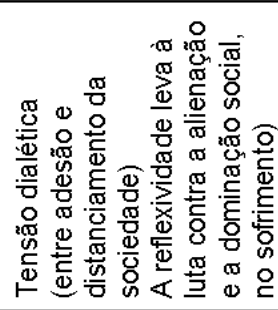 & 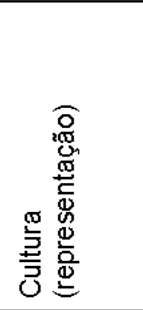 \\
\hline 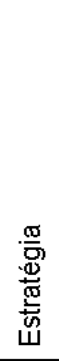 & 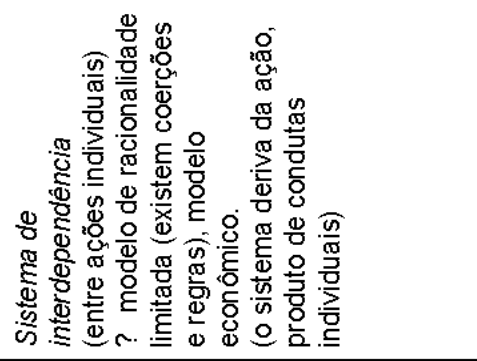 & 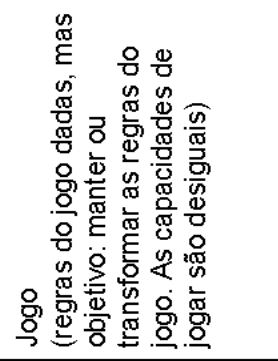 & 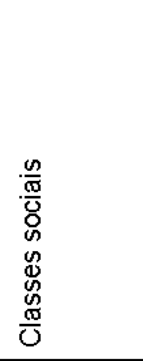 \\
\hline 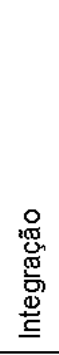 & 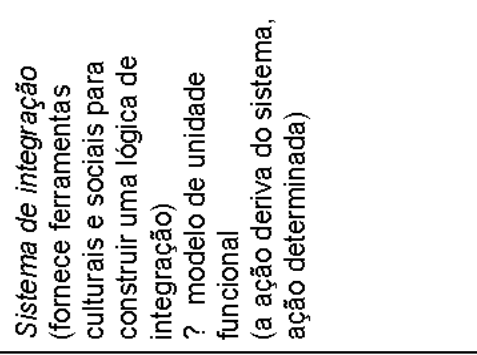 & 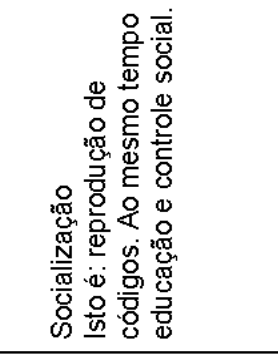 & 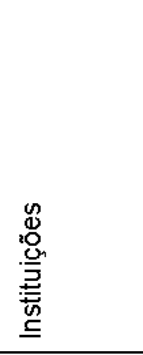 \\
\hline 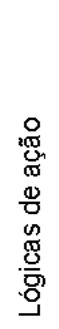 & 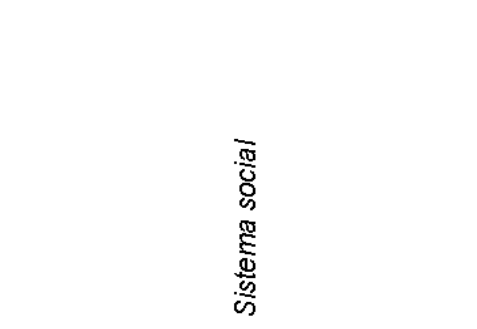 & 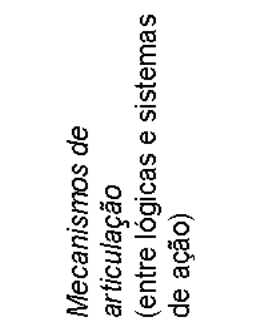 & 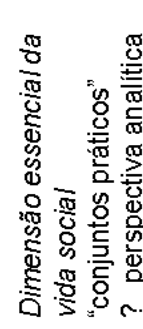 \\
\hline
\end{tabular}

Fonte: Dados elaborados a partir da obra de Dubet 
Enfim, na lógica de subjetivação, o ator pode afirmar-se como sujeito crítico, na distância ou no engajamento, na tensão "entre cultura e relações sociais, entre comunidade e mercado". O que sustenta essa lógica, é a historicidade, no sentido dado por Touraine de capacidade que uma sociedade tem para construir as suas práticas a partir de modelos culturais e através dos conflitos (Touraine, 1996, p. 11), isto é, de dar um sentido a suas práticas. Se a socialização aparecia como recurso imposto pelo sistema, o jogo de interesses como forma de manipulação pelo sistema, a historicidade, sob sua forma de tensão dialética, de "reflexibilidade", constrói-se na luta contra a alienação e contra a dominação social. E, neste sentido, esta atividade crítica pode ter, segundo Dubet, a forma de um movimento social, ${ }^{11}$ apontando para a sociedade como um sistema de ação histórica.

Existe, assim, uma pluralidade de sistemas: não há unidade do social. Cada lógica da ação remete a um sistema, a um tipo de explicação social que coexiste com outras formas de explicação, na diversidade. Numa mesma realidade social, podemos encontrar processos de socialização, mecanismos de jogo e tensão dialética. $O$ fato de que a sociedade parece coesa não significa que seja um sistema (Id., p. 150). A diversidade das lógicas de ação convida a aceitar uma diversidade de tipos de explicações e a conceber a sociedade como um todo desprovido de centro (ld., p. 152).

O ator: de que maneira constrói sua experiência e se constitui como sujeito?

A experiência social é a atividade, o trabalho pelo qual o indivíduo pode construir uma identidade social, quando articula as diversas lógicas de ação nas quais ele está engajado. Em outras palavras, é este trabalho que aproxima o indivíduo de uma representação do sujeito, e é este traba-

11 Idéia que se encontra também em Touraine: "Le retour de l'acteur"(1984) e "Pourrons-nous vivre ensemble?"(1997), entre outros escritos. 
Iho que se torna objeto de uma sociologia da experiência (ld., p. 177). Mas como isso acontece? E quais são os mecanismos que tornariam possível a passagem da experiência dos indivíduos à ação coletiva? Apoiando-se em Weber, com a noção de tensão, e em G. H. Mead, com a dissociação entre o "mim" (papel social) e o "eu" (distanciamento crítico, subjetividade), Dubet propõe uma via de compreensão desta equação, sem portanto ter a pretensão de propor uma teoria geral das regras que organizam esta atividade, uma espécie de gramática (ld., p. 177).

Segundo ele, na experiência social, as tensões existentes entre as diferentes lógicas de ação (quando há encontro ou oposição entre elas) afetam o indivíduo provocando, segundo a expressão de Weber, um "desencantamento", tornando-o um "ator dissociado". Qual seria, então, o "trabalho do ator", sua tarefa, para enfrentar esta situação? Ante as tensões existentes entre lógicas de ação, e diante das interfaces que se criam (sentimento de pertencer, ao mesmo tempo, a uma e a outra, por exemplo, lógica de integração e estratégia), o ator tenta definir suas afinidades, seus vínculos. É a construção de uma "identidade-problema", a "apresentação de $\mathrm{si}^{\prime}$ feita de tensões e sofrimentos, mesmo que disfarçados ou "rotinizados". O ator pode tentar questionar esta situação, dar-lhe um sentido. A partir do estranhamento em relação ao sistema (sentimento de não conseguir ser o que se espera dele), por meio de um movimento de distanciamento ("esta capacidade de dizer eu" constitutiva da subjetividade, Id., p. 184), ele pode criar uma postura crítica, construir uma "identidade social profunda" construindo a experiência social como sendo sua experiência (ld.). É uma atitude geradora de conflitos, de oposição à alienação, de reivindicação de autonomia, que só é possível através de uma forma de engajamento por parte dos atores, o que Dubet chama de introdução da subjetivação nas relações sociais (ld., p. 186). Assim, é o ator que articula as diferentes dimensões da ação, procurando dar sentido a suas condutas, reconstruindo sua identidade dissociada. Esta construção da ex- 
periência social está no cerne da ação coletiva em geral e dos movimentos sociais em particular. E segundo Dubet, o feliz êxito da ação coletiva não está apenas (...) na fusão da consciência individual e da consciência coletiva: ele procede também de uma autonomia individual mais forte, de uma subjetividade afirmada (Id., p. 186). Situação que ele vai ilustrar na análise da experiência da exclusão dos jovens das periferias urbanas e na experiência escolar, concluindo: o sentido da experiência social não é mais 'dado', nem pela vida social, nem pela unidade do sistema, é o produto de uma atividade (Id., p. 222). Isto é, a experiência social não só é construída, manifestada no discurso dos atores, mas ela é uma atividade crítica, uma reconstrução que só é possível porque o ator não é totalmente socializado (Id., p. 93) ${ }^{12}$ e porque ele é capaz de construir um "projeto ético": além da procura de realização pessoal, ele é capaz de ser alguém que, apesar de viver sua liberdade na angústia (diante das conseqüências de suas escolhas), quer ser autor de sua própria vida (ld., p. 99).

\section{Em que sociedade vivemos?}

Em "Sociologie de l'Expérience", Dubet fornece um quadro teórico e uma grade de análise da sociedade centrada sobre dois eixos: a ação social e a subjetividade. Em "Dans quelle société vivons-nous?", ele ${ }^{13}$ declara que, se participou, como outros autores, do movimento de desconstrução da idéia de sociedade (Dubet e Martuccelli, 2000, p. 14), ${ }_{14}^{14}$ nem por isso está renunciando à idéia de sociedade. Seu objetivo aqui é, em primeiro lugar, não ceder ao pessimismo, ao desencantamento provocado pela "cri$\mathrm{se}^{\text {" }}$ da sociedade, buscando situar-se entre idealização de um passado im-

12 No sentido dado a esta palavra pela sociologia clássica, tal como definida na p. 177.

13 Não por desconsiderar a contribuição de D. Martuccelli ao trabalho conjunto “Dans quelle société vivons-nous?"mas para simplificar a expressão, falarei, no decorrer deste artigo, da primeira e segunda obra de Dubet.

14 Sociedade tal como entendida pela sociologia "clássica" (Dubet, 1994). 
provável e o 'horror econômico' da mundialização (Id., p. 17). Em segundo lugar, ele procura redefinir a sociedade para devolver-lhe suas "capacidades de ação": daí a importância dada à temática da democracia, na luta contra a dominação e a alienação. Enfim, ele quer fazer uma tentativa de descrição articulada e raciocinada da sociedade como participação ao projeto da modernidade (Id., p. 20). Sua análise é um constante vai-e-vem entre dois planos: o teórico e o empírico, tentando explorar as tensões sociais de um ponto de vista "intelectual e prático". Após um diagnóstico da sociedade, ele analisa as esferas vinculadas ao mercado (classes sociais, trabalho e exclusão) e à comunidade (as instituições) para abrir a reflexão sobre uma nova representação da sociedade como forma de construção da experiência social.

\section{A idéia de sociedade}

A idéia de sociedade é uma representação, um tipo ideal, um objeto de conhecimento: é um conjunto de imagens, de metáforas, de histórias nas quais os atores reconheceram-se mais ou menos totalmente (...) Os atores que deixaram as maiores marcas - os movimentos sociais, os políticos, as instituiçôes como a escola - participaram amplamente desta representação (Id., p. 25). E, acrescenta Dubet, a vocação da sociologia é a construção de uma representação da vida social.

Dados estes preliminares, ele vai, como na sua primeira obra, fazer o balanço da idéia de sociedade e do mundo social hoje, como ela aparece e como está sendo interpretada. Segundo ele, a idéia de sociedade está em declínio. A representação clássica da vida social não satisfaz mais. Ela foi uma resposta às mudanças ocorridas na sociedade do Século 19, construída em volta dos eixos sociedade/modernidade, sociedade/sistema integrado, sociedade autoproduzida pelo trabalho/classes sociais e sociedade/Estado-Nação. A sociedade era interpretada como uma totalidade, um conjunto coerente e organizado no qual o ator era o sistema. 
Hoje o debate é diferente. O mundo social é um patchwork e existe uma multiplicidade de abordagens e de tentativas de interpretações: $O$ campo intelectual parece decompor-se (Id., p. 13-14). A modernidade está em crise: a história venceu o evolucionismo e o historicismo (...) A chamada mundialização não se apresenta como o triunfo da sociedade moderna universa/(Id., p. 40). A idéia de sociedade como totalidade está em declínio, dissolvida numa rede de sistemas com racionalidade própria (Dubet dá o exemplo dos sistemas autopoiéticos de Luhmann; Id., p. 44). O esgotamento da sociedade industrial, marcou o "início do fim" do movimento operário. Não significa o declínio dos movimentos sociais, mas não se pode mais sustentar a idéia de um conflito central. Enfim, o Estado-Nação encontra-se fragilizado pelas fragmentações nacionalistas e étnicas, e pela internacionalização da economia. Perda de sentido da sociedade ou busca de um outro sentido? O tema da crise está presente em todo lugar e atravessa a obra de Dubet.

Entretanto é possível reconstruir a idéia de sociedade. Como? A experiência social é a atividade pela qual cada um de nos constrói uma ação cujo sentido e coerência não são mais dados por um sistema homogêneo e por valores únicos (Id., p. 58). Redescobre-se um indivíduo cada vez mais autônomo na reivindicação da liberdade de ser o dono de si e de seus projetos, mas também cada vez mais capaz de tomar suas distâncias, de viver nas tensões. Descobre-se uma outra idéia de sociedade, caracterizada pela justaposição de elementos heterogêneos, pela separação das esferas econômicas e culturais, proporcionando o surgimento da subjetividade no quotidiano. A experiência social, como maneira de perceber o mundo, é "uma construção inacabada de sentido", que permite de "se construir", através do conflito e do engajamento na ação coletiva, e de "construir o mundo social" através de uma combinação de lógicas diferentes. 
Após uma apresentação rápida de sua teoria, Dubet traça o rumo da sua reflexão:

Se as sociedades são construídas a partir de vários princípios e várias lógicas, como nos ensina a observação das condutas sociais, é preciso tentar descrever estas lógicas a partir dos conjuntos práticos onde se realizam: as classes sociais, as instituiçôes, as representações (ld., p. 87). ${ }^{15}$

\section{Os componentes da idéia de sociedade: os "conjuntos práticos"}

As classes sociais e as relações de dominação

As classes sociais foram durante muito tempo a dimensão essencial da vida social, seu principal fator explicativo. Esta realidade está mudando: se ainda existem classes sociais, elas não dão mais conta da estrutura da sociedade, de seus conflitos e, sobretudo de sua unidade (Id., p. 93).

As três dimensões apontadas pelo autor para caracterizar as classes sociais são três chaves de análise que também encontraremos nos seus corolários: o trabalho e a exclusão. A primeira é a relação à posição social: o lugar ocupado no processo produtivo e não a função decorrente do nascimento vai definir a classe. A segunda é a comunidade de vida, os modos de vida que ela implica, a identidade induzida por ela. A terceira é a classe como ator coletivo, numa sociedade dividida, antes organizada em função de um conflito entre classes com fronteiras estanques. ${ }^{16} \mathrm{O}$ que ontem se apresentava como balizas para a compreensão da sociedade, hoje se ca-

15 Cada um destes "conjuntos práticos" é ao mesmo tempo dimensão essencial da vida social num sistema social sustentado por uma lógica específica, e também perspectiva analítica. Ver Quadro 2.

16 Dimensões nas quais se pode perceber o entrelaçamento entre as três lógicas de ação já apresentadas por Dubet: a regulação dos intercâmbios sociais, a integração e o engajamento. 
racteriza pela confusão, as cartas estão embaralhadas. Temos em primeiro lugar um "embaralhamento" das posições de classe na superposição e mistura de classes antes estanques e que hoje se subdividem. Existem hoje outras formas de divisão da sociedade. Não é mais apenas a partir da produção, mas também pela etnia, o gênero, a religião; os fatores de dominação social se diversificam, não há mais um só princípio de explicação. "Embaralhamento" das comunidades de vida, porque, se antes, a renda determinava o modo de vida das diferentes classes e as representações coletivas vinculadas a ele, hoje não é sempre o caso. As fronteiras entre classes se tornam mais fracas e transponíveis, seja em termos de progressão ou de regressão social (podemos citar o caso do jogador de futebol profissional comprado por um grande clube ou, por outro lado, do quadro de empresa desempregado).Com a mobilidade social, a distância entre classes pode até amenizar-se, mudando os estilos de vida inter ou intrageracionais. As causas são diversas - migrações internas, escolaridade mais alta, diversificação das profissões - e desafiam as análises sociológicas em termos de categorias socioprofissionais. "Embaralhamento", enfim, do vínculo entre classes e ação coletiva. Tanto na prática social quanto na análise teórica, encontram-se defensores e detratores da importância desse vínculo. Mas o fato é que surgem novas lutas sociais, novos conflitos marcados pela ambigüidade da noção de classe (por exemplo a classe dos "serviços") e pela diversidade dos modos de expressão desses conflitos (por exemplo, o movimento ecológico).

Para a análise sociológica, torna-se difícil demonstrar o vínculo entre os fenômenos de dominação, os conflitos sociais e as classes sociais, que deixam de ser grupos sociais concretos e estáveis: as posições construídas para explicar a dominação social não permitem mais descrever de maneira satisfatória a situação social de um indivíduo dado (ld., p. 116). Significaria isso o desaparecimento das classes sociais? Significa sobretudo o esgotamento de um paradigma central e o surgimento de espaços (teóricos e práticos) multidimensionais, cada um com sua lógica própria. 
Fica claro então que, apesar das mudanças que estão ocorrendo na estruturação social, não desaparecem as relações de dominação, em particular num campo econômico também em transformação profunda: o trabalho. Após anos de ouro (os chamados "Trinta Gloriosos") caracterizados pela prosperidade econômica, pela paz política e social, quando todos os sonhos da modernidade pareciam concretizar-se, a mecânica enguiçou. Mudaram os mecanismos de produção e distribuição da riqueza, de estrutura do emprego, de construção da identidade a partir do trabalho. Aqui também paira o "embaralhamento". Do ponto de vista do status do trabaIho, a instabilidade e a fragmentação do mercado do trabalho, a extensão do trabalho feminino, a diferenciação dos salários no interior de uma mesma categoria social dão uma outra definição das carreiras, da estabilidade do emprego e do status do trabalho (status precários, status de desempregado e outros). Do ponto de vista do trabalho como modo de vida criador de identidade, a significação subjetiva do trabalho muda. Se por um lado, observa-se um declínio da percepção do trabalho como sendo hegemônico, por outro lado, há revalorização do emprego, devido à extensão do desemprego. O trabalho ainda é importante para a realização de si, mas descobrem-se outros valores, não materiais, outros vínculos criadores de identidades: o trabalho ainda é o espaço privilegiado de construção de uma das representações dominantes do sujeito em nossa sociedade (...) mas não é mais verdadeiramente uma matriz de significações (Id., p. 148149). Quanto à solidariedade no trabalho, seus fundamentos são debilitados através de políticas de recursos humanos que valorizam o "capital humano", a performance, promovem a individualização das carreiras e apelam à implicação pessoal (mas no grupo) e à mobilização no trabalho. Novos conflitos e novas formas de dominação aparecem: o "culto da performance" e o "superinvestimento" físico e psíquico no trabalho apagam progressivamente as fronteiras entre vida pessoal, vida social e vida profissional, gerando efeitos perversos no quotidiano. O sofrimento do trabalho cria a "vulnerabilidade psíquica". 
Analisando a situação, torna-se difícil ainda considerar o trabalho como fator de integração social e o emprego como meio de inserção: nenhuma representação conjunta e, de momento, nenhum compromisso institucional coerente e global estão substituindo as articulações sobre as quais se fundava a sociedade industrial (ld., p. 152). Ainda permanece a concepção do trabalho como ocupação em tempo integral, por tempo indeterminado, em contradição com o desaparecimento progressivo da "civilização do trabalho". E Dubet propõe uma tipologia das possibilidades de estruturação das relações sociais pelo trabalho: as experiências são diferentes em função do status (mais ou menos protegido), da autonomia mais ou menos forte e da renda elevada ou baixa.

Antes vinculado às condições de trabalho (ou falta de trabalho), o conceito de pobreza mudou. Fala-se de "novos pobres", conseqüência do declínio da sociedade salarial que também gera novas categorias de excluídos: imigrados, mulheres. A exclusão não é mais apenas o efeito da "cri$\mathrm{se}^{\prime \prime}$, nem a diferença entre ganhadores e perdedores; é o produto de um conjunto de relações sociais e políticas, uma maneira de construir e gerenciar a sociedade (ld., p. 163). E entre as conseqüências da decomposição da sociedade industrial, está o declínio do movimento operário, já citado. O que há de interessante a ser observado neste caso, é que o resultado foi o deslocamento dos problemas sociais da fábrica para a cidade: não é mais a fábrica que encarna o escândalo da injustiça, é a periferia urbana (Id., p. 169) com seus problemas de violência, drogas e racismo.

A análise sociológica do fenômeno é fragmentada: ou se situa na análise dos mecanismos da exclusão, ou na experiência e no percurso dos excluídos. É preciso, diz Dubet, analisar a exclusão em termos de relações sociais, definir sociologicamente os grupos excluídos pela natureza de seus vínculos com o conjunto da sociedade (ld., p. 174). Ele vai prosseguir na sua reflexão seguindo a três dimensões já anunciadas: a relação à posição 
social, a relação à comunidade e a relação à ação coletiva. Assim, a exclusão é um mecanismo que atinge não só os pobres, mas ameaça também outras camadas sociais, em particular as camadas mais frágeis das classes médias: a exclusão não designa uma categoria social precisa, mas uma situação compartilhada em graus diferentes, já que não é necessário acumular todas as desvantagens para sentir-se excluído (Id., p. 174). E se as categorizações da linguagem (pobres, classes populares, classes desfavorecidas, e outras) não correspondem sempre às "categorias práticas" dos interessados, estes têm entre si um princípio de unidade: o sentimento de ser segregados, de ser estigmatizados. Mas este sentimento não é suficiente para criar uma "comunidade popular". O sentimento de desvalorização em relação às aspirações; a coabitação difícil e às vezes perigosa; a dependência dos serviços sociais e as tensões geradas nas relações com as instituições, isolam mais do que reúnem. Em situação de precariedade e de frustração, cada um vê no outro o reflexo de sua infelicidade, aquilo que ele é ou pode vir a ser.

Enfim, os excluídos são duplamente marginalizados, ao mesmo tempo no plano das relações de produção e no plano da reprodução: Existe simultaneamente uma 'luta de classes' e uma 'luta para lugares ${ }^{17}$ no meio de uma multiplicação dos níveis de participação à sociedade de consumo de massa (Id., p. 192). Desta forma, os excluídos não representam nem uma classe fechada, nem um ator coletivo, mas um problema: rejeitados por uns e 'colonizados' pelos outros (" assistência" pública), eles são vinculados à sociedade unicamente por sua identificação aos valores de consumo cujas migalhas eles aproveitam (ld.). Segundo Dubet, a exclusão não é o resultado da fatalidade ou da competição internacional, mas de um sistema complexo e diversificado de relações sociais. E ele propõe uma tipologia das "posições estruturais" encontradas na sociedade: os competitivos, os

17 Em francês: "lutte des classes" e "lutte des places". 
protegidos, os precários e os excluídos, a partir do cruzamento dos status e dos contratos de trabalho com as posições no mercado.

As instituições "desinstitucionalizadas"

A representação das instituições como sendo fundamentais porque garantem a estabilidade social e preparam atores adaptados à sociedade não cabe mais hoje. A desinstitucionalização não designa uma "crise" das instituições, mas uma maneira de ver valores e normas como "co-produções sociais". Ela gera a separação entre dois processos confundidos pela sociologia clássica: a socialização e a subjetivação (Id., p. 202).

A partir da análise de três casos (escola, família e Igreja), Dubet mostra como não existe mais homogeneidade de valores capaz de fundar a integração social, atravessados que são eles pela lógica de mercado e pela reivindicação de subjetividade. A reflexividade, a distância em relação a si, a percepção dos interesses, a construção das identidades, se tornaram princípios reguladores da ação (Id., p. 231). O que não significa que se deva abandonar o modelo de integração social porque a experiência individual que se cria através da desinstitucionalização continua sendo vivida em relações de desigualdade e sofrimento, e também porque os indivíduos procuram construir a individualidade através das identidades coletivas.

Mais a sociedade se desinstitucionaliza, mais o sujeito está definido de modo 'heróico', mais ele deve produzir ao mesmo tempo sua ação e o sentido de sua vida. Mais ele ganha liberdade, mais ele perde solidez e certezas, menos a socialização garante a subjetivação (ld., p. 238).

A desinstitucionalização coloca o indivíduo frente a provações socialmente definidas pelo seu meio. Elas são três:

- a exposição do "eu": é o princípio de responsabilidade vinculado à idéia do sujeito. A afirmação da individualidade cria a "consciência infeliz", o 
senso de culpabilidade porque, em caso de fracasso ou derrota, o indivíduo é considerado o único responsável;

- a experiência impossível: a experiência deve ser construída sobre a motivação, condição fundamental de sua autenticidade. Isso implica um "custo" psicológico caracterizado pelo distanciamento, pela crise, pela fadiga do ator (Id., p. 257);

- a experiência generalizada do "desprezo", quando o indivíduo não consegue ser dono de si mesmo, não consegue construir sua autonomia e não pode, desta maneira, ser tratado como um sujeito (por exemplo, o desempregado convidado a tomar conta de si mesmo e que não consegue, acaba acreditando que ele é o autor do seu problema, sente-se desprezado e desprezível - Id., p. 262).

As provações são o resultado do encontro entre a exigência de heroísmo do sujeito, estruturas de dominação e "chances" que o indivíduo tem ou não. Isso torna essencial o problema da construção da identidade: Como ser um sujeito individual?(Id., p. 267), como estruturar as diferenças de identidades? (gênero, sexualidade, etnia, geração). A resposta está na procura de outras formas de comunidades onde ancorar a experiência, comunidades que são "projetos" e são capazes de proteger os indivíduos.

O tema das identidades não constitui uma volta à tradição (...) ele impõe a exigência de uma nova articulação entre indivíduos e sociedade quando os valores comuns e as identidades coletivas não garantem mais um princípio de continuidade e de integração (ld., p. 300).

A representação social

O sistema de ação e representação é constituído por três conjuntos em que a idéia de sociedade se vai construindo: os movimentos sociais, o espaço público e a vida política. A hipótese de Dubet é que cada um destes 
elementos (...) fundados em princípios e lógicas autônomas, constitui o sistema de representação e de ação pelo qual se realiza hoje uma sociedade (Id., p. 307).

Os movimentos sociais são o produto de uma sociedade que é "praxis", o que explica seu papel fundamental na construção da sociedade industrial e do movimento operário "total", porque "carregam um contraprojeto de sociedade". Hoje não existe mais um movimento social central, mas mobilizações coletivas caracterizadas pelo crescimento do individualismo e da fragmentação das identidades: a coerência dos movimentos sociais não é mais dada por um só destes movimentos mas pelo 'sistema' que eles constituem e que é o sistema dos debates e as maneiras através das quais a sociedade toma conta de si mesma (ld., p. 308). Existem três formas de ação desenvolvidas pelos movimentos sociais hoje. Temos, em primeiro lugar, as lutas unidimensionais que são lutas reivindicativas, identitárias ou morais (a favor dos direitos humanos, por exemplo), lutas nas quais se cruzam a lógica do mercado, de integração social e de distanciamento crítico. Em segundo lugar, há lutas ambivalentes, em que se expressam tensões entre o instrumental e o comunitário (os imigrados, por exemplo); entre a cultura e a ação política (os ecologistas); entre mercado e sujeito (movimentos com a participação de voluntários: movimento feminista, por exemplo). Enfim, existem as lutas que reúnem todas as dimensões da ação, muitas vezes de maneira conjuntural, movimentos que vão orientar sua ação em torno de diferentes maneiras de lutar contra a dominação e a mudança não-controlada, como, por exemplo, em torno da temática da competição mundial e/ou da defesa dos direitos sociais. Assim, a sociedade é um campo de lutas esparsas que tentam, cada uma a seu modo, articular orientaçôes sociais heterogêneas (ld., p. 336) e de movimentos sociais acionados esporadicamente, segundo as circunstâncias. Entretanto, aparentemente frágeis, eles conseguem mexer com a sociedade.

A mídia "de massa", em particular a televisão, é um aglomerado múltiplo e heterogêneo que abre espaço para vários tipos de interpretação 
social. Objeto de propaganda e de alienação, ela é também "espelho", e não apenas "janela", isto é espaço de projeção da sociedade e dos indivíduos (Id., p. 358), espaço de socialização, ela revela os problemas sociais, ensina estratégias de comportamento. A experiência do telespectador se constrói, assim, na tensão entre diferentes lógicas que se confundem. A televisão é um objeto de consumo, mas também é uma forma de vínculo social (e assim produz sentido); ela também permite um distanciamento na formação e expressão da opinião (sobre o conteúdo dos programas ou sobre a própria TV). Desta forma, a televisão é um palco de representação social, e a mídia em geral não só dá uma definição do mundo, mas o registra e o constrói (ld., p. 369).

Quanto ao "político", nota-se hoje um enfraquecimento de suas duas dimensões fundamentais: a dimensão simbólica (o elemento "paixão", a ideologia) e a dimensão funcional (o elemento racional, isto é o direito, a integração prática). Questiona-se então o Estado sobre sua capacidade de integração, crítica da burocracia, da noção de "interesse da Nação". Ocorrem mudanças:

- na intervenção pública: na monitorização da economia pelo Estado (instauração de políticas de "modernização" do Estado) e no gerenciamento da crise social (instauração de reformas institucionais baseadas na descentralização). Instaura-se uma política visando estabelecer a sociedade como projeto, como combinação de exigências contraditórias através de políticas públicas, mais do que pela afirmação de uma legitimidade e de uma racionalidade geral(ld., p. 384);

- na representação política: instabilidade do eleitorado e erosão do vínculo simbólico entre o indivíduo e as instituições, através do político (Id., p. 385), entre o indivíduo e o Estado. Alem do mais, assiste-se ao declínio da "polarização política" entre a esquerda e a direita.

Deste modo, a esfera política não é mais hegemônica e se divide em três espaços independentes, mas rivais: o espaço político, a opinião pública 
e a ação coletiva, que geram reflexividade e capacidade de distância. O espaço político, onde cresce a capacidade individual do cidadão de julgar as práticas políticas, denota um progresso da democracia. É a opinião pública que invade o espaço público. Por outro lado, a ação coletiva, com sua vontade de restabelecer uma relação entre a atividade social e a manifestação da vontade política constrói um espaço de representação paralelo ao espaço dos partidos (Id., p. 396). Se assistimos ao declínio da capacidade de informação e de formação de opinião da sociedade por parte do sistema político em benefício da mídia e da ação coletiva, ele ainda tem a maior capacidade de ação. Temos assim três espaços de construção da idéia de sociedade que se desenvolvem através dos conflitos e das capacidades de ação; não são nem sistema natural nem contrato, mas capacidade de articulação de lógicas diferentes.

Concluindo sua obra, Dubet insiste sobre o esgotamento das duas temáticas que fundaram a idéia de sociedade, a saber as classes sociais e as instituições, mesmo que a dominação social não desaparece. Ela tomou uma outra forma: fraturas sociais e desigualdades são o resultado das tensões que se estabelecem entre o econômico e o social. A idéia de sociedade deve ser construída na mudança, na consciência de seu inacabamento, porque ela é dinâmica, é o resultado de um trabalho constante. É na autorepresentação que se constrói hoje a idéia de sociedade, através de um conjunto de imagens, de desafios e de debates dos quais ela é objeto (Id., p. 412). E a condição fundamental da construção da sociedade é a democracia: é ela que produz uma verdadeira representação da vida social, através do jogo dos atores. 


\section{Compreender Dubet}

\section{A pertinência da análise}

François Dubet é um sociólogo francês, e seu campo de pesquisa empírico é a França, com suas instituições, seu sistema político e seus problemas sociais. O seu objetivo não é fazer um estudo comparado que teria a finalidade de construir um "tipo" de sociedade: a tarefa, muito complexa, corre o risco de ser caricatural, pensa ele. Ele opta então por uma observação minuciosa da França, reconhecendo não ser a solução mais elegante nem a mais brilhante (Dubet e Martuccelli, 2000, p. 17). A outra razão dessa opção é que, segundo ele, os modelos de mudança adotados na modernização são múltiplos e originais, visto que cada sociedade gerencia e ordena sua transformação de maneira "nacional".

Esta advertência inicial permite uma atitude crítica em relação à Sociologia da Experiência e a seus eventuais limites em relação à realidade brasileira. Poder-se-ia perguntar se o conceito de "experiência social" pode levar à compreensão das expressões contemporâneas da sociedade brasileira? Quais seriam os modos originais de "ordenar sua transformação?" A validade da teoria foi demonstrada num contexto cultural preciso: a França. Mas no Brasil, vive-se, de maneira bem mais evidente, a contradição e a competição entre as instâncias da comunidade, do mercado e da autonomia Aqui os atores ainda estão muito determinados pelos papéis (o "Doutor", o "Coronel"), num jogo de relações de dominação e de dependência (clientelismo, corrupção), que ainda é um traço marcante da cultura sullatina, tanto na Europa, como na América. Ademais, a experiência social moderna é caracterizada, segundo Dubet, não só pela diversidade das lógicas de ação, mas também pela exigência de individualização, ${ }^{18}$ em

18 Isto é: de diferenciação, de reconhecimento (para uma pessoa ou uma comunidade) de características próprias. O termo não tem nada a ver com "individualismo", no seu sentido utilitarista e egocêntrico. 
contraposição à homogeneidade funcional e à institucionalização das condutas. Na pobreza, injustiça, exclusão social, violência e abandono institucional, que têm no Brasil um peso maior no quotidiano, a questão não seria só a reivindicação de individualização por parte dos atores, mas das condições de surgimento e desenvolvimento da reflexividade, da capacidade de distanciamento crítico como fundamento da subjetivação. É um problema vinculado à socialização (não apenas formação, mas educação à sensibilidade social), à história de vida de cada um e à estrutura da sociedade brasileira A existência do sujeito só é possível numa sociedade que produz as condições culturais de surgimento de um sujeito social, lembra Dubet. E, de fato, que parcela da população brasileira vive em condições que lhe permitam tencionar ser um sujeito social (isto é, aquele que pode questionar-se, criticar, organizar-se) mesmo em movimentos sociais? E será ela reconhecida como tal pelos próprios atores sociais?

Mais profundamente, o que se deve perguntar, é o que Dubet entende mesmo quando ele fala de "Sujeito"? O conceito, prolongamento da reflexão feita por Touraine, não aparece bem claro e necessita uma explicação mais fina. O Sujeito não é um estado de fato. Segundo o próprio Dubet, ${ }^{19}$ o Sujeito não existe. É um tipo ideal, uma construção cultural. O que existe é o sentimento de ser sujeito, de construir sua vida em adequação com aquilo que se tenciona ser. É uma aproximação, um projeto não apenas individual, mas também social (elaborado nas relações sociais). Este projeto passa pela construção da experiência social, pela articulação entre lógicas de ação diferentes e vinculadas a um sistema social. Construção realizada no conflito e no sofrimento: não há sempre possibilidade de "encaixamento" entre as diversas lógicas, mas nem por isso enguiça necessariamente o "trabalho" do ator na sua aproximação da representação do Sujeito. Este, afinal, poderia ser caracterizado como sendo um processo,

19 Intervenção no seminário ministrado por Dubet no CADIS - Paris, ano acadêmico 2002. 
uma dinâmica original... não forçosamente a mesma no Brasil e na França. O que sugere Dubet quando fala de ordenação "nacional" das sociedades.

Essas considerações não diminuem em nada o interesse do estudo de Dubet para a sociedade brasileira, pelo contrário. Em primeiro lugar, pelo caráter extensivo de seu quadro teórico; ${ }^{20}$ lógicas de integração e lógicas estratégicas impregnam a sociedade brasileira tanto quanto a francesa, e não faltam exemplos na história recente. Em segundo lugar, numerosos problemas e práticas sociais se assemelham: violência, racismo, gênero, "crise" sindical, mídia, vida política, movimentos sociais, mesmo que seu surgimento seja vinculado a uma história diferente. Num caso como no outro, são as respostas que diferem, já que, afinal, segundo Dubet, a sociedade é o que fazem dela os atores individuais e coletivos. Finalmente a questão levantada por Dubet, o lugar da subjetividade na ação social, está atualmente também em debate na sociologia brasileira, que tem as mesmas referências clássicas que a sociologia francesa, ainda que com ênfase diferente. Pelo menos dois estudos recentes colocam a subjetividade no centro do debate sociológico no Brasil. O primeiro, desenvolvido por Ricardo Antunes ${ }^{21}$ centra a reflexão sobre o sentido do trabalho. Segundo ele, precisa-se adotar uma concepção abrangente e ampliada do trabalho, que o contempla tanto na sua dimensão coletiva quanto na subjetiva (Antunes, 2000, p. 182), o que ele chama de "subjetividade dotada de sentido". Quanto a José Maurício Domingues, ${ }^{22}$ numa perspectiva mais ampla de reflexão sobre a teoria social hoje e de compreensão da "modernidade contemporânea", ele utiliza o conceito de subjetividade coletiva para explicar os fenômenos coletivos, numa reflexão cujas grandes linhas parecem aproximar-se das obras estudadas neste artigo.

\footnotetext{
20 Fato demonstrado pelo próprio autor nos seus estudos empíricos, nos quais tenta entender o surgimento e o sentido de ações desenvolvidas por atores específicos (jovens marginalizados, alunos e professores, enfermeiros, trabalhadores sociais), assim como de situações que são o resultado da transformação da sociedade: mudanças no mundo do trabalho "para os outros", a exclusão social e a desigualdade (ver a bibliografia das obras de Dubet).

21 "Os sentidos do trabalho": ver bibliografia.

22 "Criatividade social, subjetividade coletiva e a modernidade brasileira contemporânea": ver bibliografia.
} 


\section{A contribuição de Dubet à construção do pensamento social}

O fato que talvez chama mais a atenção na leitura de Dubet é sua preocupação com o caráter unívoco do quadro clássico de análise da sociedade. Ele propõe uma "desconstrução" desse quadro, sem, no entanto, renegá-lo, e, muito pelo contrário, apoiando-se nele para pôr um olhar novo sobre a realidade e suas representações. Assim como Simmel, ele soube 'dedatar' o que pertence ao passado tornando-o ao mesmo tempo presente e reflexão crítica sobre o futuro (Vieillard-Baron, 1989, p. 27). Em nenhum momento ele rejeita a leitura clássica, em nenhum momento ele dicotomiza o ator e o sistema (ele é ou não é sistema), mas procura uma mediação, uma síntese entre as contradições aparentes da sociedade de hoje e a continuidade existente entre essas contradições: a permanência do fenômeno da dominação, a permanência da alienação, apesar das mudanças ocorridas.

Destaca-se também a continuidade e a coerência da reflexão na construção do quadro de análise e na sua operacionalização, fundamentada na escuta do ator, o que ele tem a dizer sobre sua vida, sua experiência, na procura das diferentes lógicas presentes no discurso e nas estratégias, na recomposição e no cruzamento dessas lógicas, a fim de reconstruir a experiência social. Este método, na linha da intervenção sociológica de Touraine, deve ser adaptado a cada caso concreto e transparece de maneira bem clara nas pesquisas que exemplificam a teoria (Dubet, 1994).

Em "Sociologie de l'Expérience", ele apoia sua teorização no estudo crítico dos clássicos da sociologia, mas também traça um quadro das tentativas de compreensão da sociedade de hoje pelas teorias contemporâneas, caracterizadas pela diversidade e pela heterogeneidade. O que, segundo ele, pode "costurar" essa diversidade é a experiência social como modo de ação social assentada na subjetividade do ator. Os dois conceitos chave 
- ação e subjetividade - são lançados e vão atravessar toda a sua reflexão, seja para se contrapor às lógicas da modernidade clássica, seja para demonstrar sua coexistência na construção da experiência social. Talvez se possa lamentar que, na apresentação de Dubet, a descrição da lógica de subjetivação pareça às vezes um pouco abstrata, principalmente na sua referência ao sistema social: a idéia de democracia, não apenas tipo de governo, mas condição de construção das experiências sociais (Dubet, 1994, p. 262) aparece apenas na conclusão, como espécie de tributo ao pensamento de Touraine. A idéia será retomada e bem mais desenvolvida na sua análise da sociedade francesa. Também, quando ele tenta mostrar como se dá a passagem para a ação coletiva através do conflito, "pelo engajamento que ele implica" (Id., p. 186), o autor não só revela sua postura militante como deixa uma dúvida: será que todo conflito resulta mesmo em engajamento coletivo? E que tipo de engajamento? O movimento social, particularmente destacado por Dubet não é o único exemplo de concretização do "trabalho" do ator (ele pode estar presente nas ONGs, entre outros exemplos).

A reflexão teórica vai ser concretizada em "Dans quelle société vivonsnous?". A mensagem de Dubet: "não há unidade do social" será apresentada nessa obra de maneira muito mais prática, apoiada numa revisão bibliográfica ampla e crítica para cada assunto tratado. Após esclarecer o quadro geral da reflexão, isto é, a crise da sociedade (francesa) manifestada no declínio da representação da sociedade e no surgimento da afirmação da autonomia individual, Dubet vai analisar três dimensões centrais para os tipos de explicações da sociedade fornecidas pela sociologia: classes sociais, instituições e cultura que são as dimensões analíticas (já fornecidas em "Sociologie de l'Expérience") que permitem entender o contexto da obra. No decorrer desta, o autor vai passar da descrição de fatos empíricos, largamente documentados, às pistas para a compreensão, passando pela reflexão sociológica crítica. Para cada dimensão abordada, suas 
variáveis de análise serão as categorias selecionadas na teoria: natureza das relações sociais, o que fundamenta a ação dos atores e a referência ao sistema social (ver quadros 1 e 2). Coerentemente com sua teoria, para cada dimensão, Dubet sublinha a necessária articulação entre as diferentes lógicas e o vínculo destas com os mecanismos que articulam lógicas e sistemas sociais. Resulta um estudo extremamente coerente, mas cuja lógica não aparece à primeira leitura. Sem uma boa assimilação da teoria apresentada no seu primeiro livro, o segundo aparenta ser um grande afresco, o romance social da "grandeza e decadência da idéia de sociedade" cujo grand fina/ não fica bem claro: como sair deste caos? E se corre o risco de perder a riqueza e a originalidade do trabalho. Mas, afinal, Dubet é fiel a seu discurso: ler esse livro é um exercício prático de experiência social na tensão entre a co-construção do conhecimento e a tentação de recaída na lógica pedagógica tradicional!

\section{Os conceitos-chave}

Dois conceitos perpassam a obra de Dubet: ação social e subjetividade. Mas nem esses conceitos nem a preocupação do autor em propor uma ação social subjetiva são novidade no pensamento sociológico. A insatisfação com as explicações totalizantes da sociedade faz a teoria social se voltar para uma releitura dos clássicos (muitos dentre eles esquecidos) e para explicações fundadas no paradigma da ação social; será o caso de Touraine, presente em toda a obra de Dubet. Estas duas atitudes provocam também o triunfo das micro-sociologias, do interacionismo (Dubet e Martuccelli, 2000, p. 13). É este mesmo caminho que Dubet vai seguir.

É clara a referência à corrente interacionista: Mead, Schutz, Goffman e, através deles, dos clássicos "inspiradores", aqueles que recolocam no centro do debate o indivíduo, sua ação, sua busca de sentido: Simmel, Weber, mas também Mauss. Os limites deste artigo não permitem infelizmente mergu- 
Ihar na obra destes pensadores para destacar os traços comuns, os paralelismos do pensamento, enfim, a herança deixada a Dubet. Mas não deixa de ser tentador aproximar alguns aspectos com pinceladas rápidas. Assim, Georg Simmel, faz uma pergunta cujo sentido reencontramos em Dubet: "Como é possível a sociedade?", "sob que condições?". ${ }^{23,24}$ Ele vai construir sua reflexão na linha do pensamento de Kant: O conhecimento não é regulado pelos objetos, mas são os objetos que regulam o conhecimento, isto é, uma coisa existe quando pode ser posta pelo sujeito do conhecimento (Kunzmann e outros, 1994, p. 137). Segundo Simmel, a sociedade existe no sentido amplo da palavra, quando existe uma ação recíproca dos indivíduos. ${ }^{25} \mathrm{~A}$ sociedade nasce então das interações entre indivíduos, e Simmel demonstra preocupação em manter o lugar do indivíduo no social, mas também sublinha como a sociedade vive a tensão entre a tendência à continuidade e coesão que lhe permite manter-se, e a tendência à divisão, que é reivindicação individualista do pensamento moderno. Para ele, o individualismo é um componente essencial da modernidade; responsável dele mesmo, o homem moderno ressente uma inquietude permanente (Vieillard-Baron, 1989, p. 33). O individualismo é tensão, é reivindicação de liberdade pessoal, é autonomia: a determinação indefinível da vida que chamamos individualidade significa que um ser vive ao mesmo tempo (...) o ser 'eu' auto-suficiente e (...) a tendência a identificar-se ou a retirar-se, em relação a um todo ao qual pertence o ser (Simmel, 1989, p. 283, tomo 1). Este respeito da dimensão individual do homem e suas preocupações com as transformações da sociedade sublinham a modernidade de Simmel.

Estas pinceladas, evidentemente insuficientes, podem, entretanto, apontar para elementos fundamentais desenvolvidos por Dubet. O resgate da individualidade, as tensões presentes na sociedade e no indivíduo, a

23 Simmel. "La sociologie de l'expérience et du monde moderne", citado por Vieillard-Baron (ver bibliografia) 24 Dubet e Martuccellei. "A sociedade é sociedade porque ela não pára de se perguntar sob que condições a vida social é possível", 2000 , p. 373.

25 Simmel. "Sociologie et Epistémologie", 1981, p. 165. Citado por Durand e Weil (ver bibliografia). 
ação recíproca criadora de sociedade, a reivindicação de autonomia, são temas permanentes da análise de Dubet. O paralelismo pode continuar com os textos de Simmel sobre o conflito e sobre a modernidade, cuja figura emblemática é o estrangeiro (Dubet, 1994, p. 74). ${ }^{26}$

Alfred Schutz também deixa sua marca nos textos de Dubet; pouco citado, talvez, mas sua fenomenologia social transparece em toda a obra. Inspirando-se em Weber (a sociologia compreensiva) e em Husserl (a fenomenologia), Schutz vai desenvolver uma sociologia das relações entre atores individuais dentro do quadro da vida quotidiana; é o que fundamenta sua teoria da ação. Dois conceitos (entre outros) se destacam:

- O mundo da vida:

o mundo da vida cotidiana significará o mundo intersubjetivo que existia muito antes de nosso nascimento, vivenciado e organizado por outros (...) Ele se dá à nossa experiência e interpretação. Toda interpretação deste mundo se baseia num estoque de experiências anteriores dele (...) O mundo da vida cotidiana é a cena e também o objeto de nossas açôes e interações (...) Mundo, neste sentido, é algo que temos de modificar, através de nossas ações, ou que modifica nossas ações (Wagner, 1979, p. 72-73).

- A intersubjetividade:

o mundo da minha vida diária não é de forma alguma meu mundo privado, mas é, desde o início, um mundo intersubjetivo compartilhado com meus semelhantes, vivenciado e interpretado por outros (Id., p. 159). E o alter ego significa que o outro é como eu, capaz de agir e de pensar (Id., p. 161). A ação é uma conduta que é prevista e a conduta, as experiências de significado subjetivo que emanam de nossa vida espontânea (Id., p. 123).

26 Idéia que também se encontra em Schutz (o estranho) e em Touraine (o imigrado: "Pourrons-nous vivre ensemble". Fayard, 1997). 
As noções de "estoque" de experiência e de conhecimentos, o mundo da vivência compartilhada, intersubjetiva, no mundo da vida diária, como também a noção de ação como capacidade de construir o mundo, não são apenas retomados formalmente por Dubet (Dubet, 1994, p. 81), mas atravessam toda sua Sociologia da Experiência. Poderíamos citar também a interessante análise que Schutz faz do grupo (e os significados objetivo e subjetivo de pertencer a um grupo, introduzindo a figura do "estranho") e da linguagem como "meio social de orientação e interpretação", também retomada por Dubet (ld., p. 84).

\section{Conclusão}

Não cabe concluir este estudo apenas esboçado. A apresentação da obra de Dubet poderia ser agora completada, tanto do ponto de vista teórico como do ponto de vista empírico.

- Teórico: completando esta volta às origens do pensamento do autor, não por satisfazer uma sede de erudição, mas para melhor entender as continuidades e descontinuidades entre o pensamento clássico e a teoria social contemporânea e melhor fundamentar a análise de aspectos particulares de nosso quotidiano que são herança da sociedade industrial (o trabalho, por exemplo).Também, neste campo disperso e nesta multiplicidade de paradigmas denunciado pelo próprio Dubet (Dubet, 1994, p. 11), seria interessante comparar a sua perspectiva com a dos outros sociólogos que compartilham a mesma preocupação de entender as transformações de nossa sociedade, a fim de tentar fazer aqui nossa própria "experiência" de reconstrução do social, tarefa nada fácil.

- Empírico: aplicando a grade de análise oferecida por Dubet à realidade de nossa vida cotidiana, aqui no Brasil. O que, aliás, poderia fornecer um estudo comparativo interessantíssimo entre situações vividas no Norte e no Sul do planeta. Por exemplo: os bandos de jovens e a vio- 
Sociologias, Porto Alegre, ano 5, no 9, jan/jun 2003, p. 174-214

lência, a transformação das relações intergerações na família e as novas solidariedades, o surgimento dos grupos neonazistas e as relações entre etnias no Brasil, os movimentos sociais, entre outros tantos fenômenos.

A descoberta da Sociologia da Experiência foi a ocasião de realizar uma viagem através do pensamento sociológico histórico e contemporâneo, rica em descobertas e reflexões que, infelizmente, não podem ser traduzidas no quadro restrito deste artigo: experiência de distância e engajamento, de tensão e sofrimento, de construção de uma reflexão social que, ao mesmo tempo, dá a medida de nossas lacunas, mas também abre perspectivas para uma representação crítica da sociedade, de seus mecanismos, de suas dimensões. Trabalho sempre inacabado...

\section{Referências}

ANTUNES, Ricardo. Os sentidos do trabalho. Ensaio sobre a afirmação e a negação do trabalho. 2ª ed. São Paulo: Boitempo, 2000.

DUBET, François. Sociologie de I'expérience. Paris: Seuil, 1994.

DUBET, François e MARTUCCELLI, Danilo. Dans quelle société vivons-nous? Paris: Seuil, 1998. Ed. Argentina: i En qué sociedad vivimos? Buenos Aires: Losada, 2000.

DURAND, Jean Pierre e WEIL, Robert. Sociologie contemporaine. Paris: Vigot, 1993.

DOMINGUES, José Maurício. Criatividade social, subjetividade coletiva e a modernidade brasileira contemporânea. Rio de Janeiro: Contra Capa, 1999.

KUNZMANN, P., BURKARD, F. P., WIEDMANN, F. Atlas de Philosophie. Paris: Librairie Générale Francaise, 1994.

SIMMEL, Georg. Philosophie de la Modernité. Paris: Payot, 1989. Vol.1 e 2. 
TOURAINE, Alain. Le retour de I'acteur. Paris: Fayard, 1984. Tradução portuguesa: O retorno do actor. Lisboa: Instituto Piaget, 1996.

TOURAINE, Alain. Pourrons-nous vivre ensemble? Paris: Fayard, 1997.

VAN METER, Karl M. (org.) La Sociologie. Textes essenciels. Paris: Larousse, 1992. VIEILLARD-BARON, Jean Louis. Introdução a Georg Simmel. Philosophie de la Modernité. Paris: Payot, 1989. Vol.1 e 2.

WAGNER, Helmut R. (org.) Fenomenologia e relações sociais. Textos escolhidos de Alfred Schutz. Rio de Janeiro: Zahar, 1979.

As obras mais importantes de Dubet:

La galère: jeunes en survie. Paris: Fayard, 1987.

Les lycéens. Paris: Seuil, 1991.

Les quartiers d'exil (com Didier Lapeyronnie). Paris: Seuil, 1992.

Sociologie de I'expérience. Paris: Seuil, 1994.

A l'école. Sociologie de l'expérience scolaire (com Danilo Martuccelli). Paris: Seuil, 1996.

Ecole, familles: le malentendu (org.). Paris: Textuel, 1997.

Dans quelle société vivons-nous? (com Danilo Martuccelli). Paris:Seuil, 1998.

Pourquoi changer l'école? Paris: Textuel, 1999.

L'hypocrisie scolaire. Pour un collège enfin démocratique (com Marie Duru-Ballat). Paris: Seuil, 2000.

Le déclin de l'institution. Paris: Seuil, 2002. 
Sociologias, Porto Alegre, ano 5, no 9, jan/jun 2003, p. 174-214

\section{Resumo}

O objetivo deste artigo é divulgar um pensamento sociológico ainda pouco difundido no Rio Grande do Sul: a Sociologia da Experiência, teorizada pelo sociólogo francês François Dubet. Pretende-se aprofundar a compreensão dos conceitos por ele desenvolvidos, não só do ponto de vista teórico, mas também nas suas possibilidades de aplicação ao campo empírico. É a razão pela qual será feita a síntese de duas obras de Dubet: Sociologie de l'Expérience (Sociologia da Experiência) e Dans quelle société vivons-nous? (Em que sociedade vivemos?), numa tentativa de entender as expressões contemporâneas da sociedade, na sua aparente crise de valores, ambigüidades e incoerências. A reflexão desembocará num conjunto de perguntas ainda em aberto: qual o interesse da Sociologia da Experiência para a sociedade brasileira?

Palavras-chave: experiência social, lógicas de ação, ator social, subjetividade. 